\title{
WAHYU PERTAMA AL-QUR'AN SEBAGAI PONDASI METAFISIKA PENDIDIKAN ISLAM
}

\author{
Muh. Iqbal \\ 1* Magister Pendidikan Agama Islam, Universitas Ahmad Dahlan, Yogyakarta, Indonesia \\ * Coresponding author
}

\section{ARTICLE INFO}

Article History

Received:

Revised:

Accepted:

Keyword: :

Philosophy, Metaphysics,

Islamic Education, Revelation

Kata kunci: Filsafat, Metafisika, Pendidikan Isam, Wahyu

\begin{abstract}
There are three aspects of education that can be taken from the first five verses of surah Al-Alaq, is divine education (Tauhid), intellectual education (intellect) and skills education. Education cannot be separated from things that are free from physical reach (metaphysics), for example tauhid education, the delivery of material or lessons must be in accordance with facts, not just fantasies, assumptions, and illusions. This paper uses a library research with data sources in the form of scientific articles, books, documents, journals, and other sources that are library in nature. The data collected was then analyzed in depth with content analysis techniques and presented descriptively. The result is the first revelation which contains metaphysical elements such as the essence of God, His creation and humans so that metaphysics cannot enter from Islamic education. The process of Islamic education to achieve the goal of education is the realization of humans who have good beauty potential to support humans in carrying out their duties and positions on earth, namely as servants and caliphs.
\end{abstract}

\section{ABSTRAK}

Terdapat tiga aspek pendidikan yang dapat di ambil dari lima ayat pertama surat Al-Alaq yakni pendidikan ketuhanan (tauhid), pendidikan akal (intelek), dan pendidikan keterampilan. Pendidikan tidak dapat di lepaskan dari hal-hal yang bersifat di luar jangkauan fisik (metafisika) misalnya pendidikan tauhid, penyampaian materi atau pelajaran harus sesuai dengan fakta bukan hanya sekedar khayalan, asumsi dan ilusi semata. Tulisan ini menggunakan studi kepustakaan (library research) dengan sumber data berupa artikel ilmiah, buku, dokumen, jurnal serta sumber-sumber lain yang bersifat kepustakaan. Data di kumpulkan kemudian di analisis secara mendalam dengan teknik analisis isi (content analysis) dan di sajikan secara deskriptif. Hasil penelitian berupa wahyu pertama mengandung unsur-unsur metafisika seperti hakikat Tuhan, ciptaan-Nya dan manusia sehingga metafisika tidak dapat di pisahkan dari pendidikan Islam. Keindahan dan ber nilainya suatu proses pendidikan Islam apabila tujuan pendidikan tercapai yaitu terwujudnya manusia yang memiliki potensi yang baik guna mendukung manusia dalam melaksanakan fungsi dan kedudukannya di muka bumi yakni sebagai hamba dan khalifah. 


\section{PENDAHULUAN}

Wahyu (Al-Qur'an) adalah firman Allah yang diturunkan kepada Nabi Muhammad melalui malaikat Jibril yang menjadi sumber dari ajaran umat Islam itu sendiri. Menurut 'Allamah Thabathaba'i “Al-Qur'an mengajak manusia untuk mempelajari ilmu-ilmu alam, matematika, fisika, filsafat, dan segala ilmu pengetahuan yang mampu di capai oleh manusia" (L. Rusliana, 2015). Wahyu pertama diterima oleh Nabi Muhammad adalah Surat Al-Alaq ayat 1-5 di gua Hira. Sebagai tuntunan hidup umat Islam, Al-Qur'an mampu memberikan jawaban terkait ilmu-ilmu yang belum mampu diungkap oleh manusia. Misalnya hakikat dan realitas Tuhan itu ada atau tidak? (G. R. Knight,2007). Pertanyaan seperti ini menjadi bagian dari metafisika dalam filsafat. Konsep dan proses pendidikan harus sesuai Al-Qur'an agar tidak menimbulkan kesalahan dalam pendekatan terhadap ilmu, misalnya akal di pertentangkan dengan Al-Qur'an. Sebagaimana di ketahui bahwa Al-Qur'an sebagai induk ilmu pengetahuan dan salah satunya adalah filsafat sebagai disiplin ilmu yang berorientasi mencari dan mengungkapkan hakikat. Maka sangat perlu kita memahami bagaimana hakikat wahyu yang pertama turun dalam membangun term pendidikan Islam baik salah satunya segi term metafisika. Metafisika adalah salah satu bagian ilmu filsafat yang mengkaji tentang hakikat dan realitas keberadaan (R. Mustansyir dan M. Munir, 2015).

Metafisika sebagai akar persoalan realitas, tentunya harus di pahami dan di terapkan dalam aspek kehidupan tidak terkecuali pendidikan. Banyak persoalan di dalam pendidikan yang memerlukan pemahaman metafisika. Misalnya seperti peserta didik jenuh akibat sekolah diliburkan terlalu lama (A. Purwanto dkk, 2020). Metafisika pendidikan sebagai salah satu cara mencegah peserta didik melakukan hal-hal yang bersifat negatif (begadang, bermain game secara berlebihan, dll) akibat kejenuhan dari sekolah yang di liburkan terlalu lama sebagai dampak dari pandemi. Persoalan seperti ini sangat penting mengingat di dalam metafisika terdapat pendidikan terkait ketuhanan atau pendidikan spiritual yang akan memicu meningkatnya kecerdasan spiritual sebagai salah satu pendorong otak dalam berfikir secara rasionalTentunya masih banyak persoalan pendidikan lainnya yang dalam penyelesaiannya perlu penerapan metafisika (Suyadi, 2017).

Berbagai penelitian memberikan gambaran bahwa metafisika itu sangat penting dalam pendidikan. Sejauh ini berbagai penelitian hanya mengungkapkan dengan ontologi, ataupun sebatas penjabaran terkait epistemologi dan aksiologi pendidikan. Pendidikan Islam sebagai jalan untuk mengoptimalkan potensi agar terwujud umat Islam yang holistik serta mampu mencapai Ridha Allah tentunya harus dibangun dan berlandaskan sumber ajaran Islam. Tanpa memahami konsep Metafisika pendidik akan sulit dalam menjelaskan persoalan yang tidak dapat di jangkau akal atau melampaui fisik serta sulit dalam mengkaji lebih jauh karena persoalan dasar belum terungkap ( $\mathrm{M}$. R. Dasuki, 2019). Pendidik yang profesional haruslah memahami mata pelajaran yang akan diajarkan (W. Fajriana, 2019). Salah satu cara untuk memahami isi materi pelajaran khususnya Pendidikan Islam tentunya harus memahami metafisika. 
Tujuan penelitian ini untuk menganalisis surat Al-alaq khususnya ayat 1-5 sebagai landasan metafisika pendidikan Islam. Di dalam penelitian ini akan di uraikan wahyu pertama dan bagaimana wahyu pertama di jadikan sebagai landasan metafisika pendidikan dan kaitannya dengan pendidikan masa kini yang akan di jabarkan dalam setiap penjelasan cabang-cabang metafisika seperti kosmologi, teologis, antropologi dan ontologi. Dengan penelitian ini diharapkan wahyu pertama dapat dijadikan sebagai contoh dan pijakan dalam proses pendidikan Islam khususnya terkait hal-hal yang bersifat metafisika.

Penelitian ini di dasarkan pada argumen bahwa pendidikan Islam tidak dapat menghindari dunia metafisika sebagai kajian realitas puncak dan menjadi pusat konsep dari apapun dalam pendidikan (G. R. Knight, 2007). Misalnya seperti konsep ketuhanan, dalam Islam bahwa Tuhan itu satu sedangkan kepercayaan lain belum tentu sama. Pentingnya pemahaman metafisika hal ini karena secara langsung mempunyai pengaruh terhadap isi kurikulum ataupun sistem pendidikan. Terlebih lagi seiring perkembangan zaman tanggung jawab seorang pendidik semakin berat (A. W. Fajriana, 2009). Metafisika juga dapat dijadikan sebagai cara pengurangan perilaku negatif dampak dari kejenuhan akibat pandemi.

\section{METHODE PENELITIAN}

Jenis metode penelitian yang digunakan dalam tulisan ini adalah kajian kepustakaan (Library research) sebagai cara untuk menggali informasi atau data yang bersumber dari karya ilmiah, artikel jurnal, buku, dan sumber lainnya yang bersifat kepustakaan. Metode yang digunakan yakni kualitatif deskriptif dengan

Analisis data dilakukan dengan teknik Reduksi data untuk memilah sumber data yang ditemukan, hal ini bertujuan untuk mencegah adanya penumpukan data yang sama. Langkah yang di lakukan seperti merangkum, memilah dan lebih berpusat pada informasi yang penting. Analisis isi (Content Analysis) dimana memaparkan secara mendalam terhadap ini atau informasi yang termuat di dalam sumber data (Emzir, 2009). Pengumpulan data dilakukan dengan cara mengumpulkan kajian-kajian yang terkait dengan tema penelitian yang kemudian di analisis secara deskriptif.

\section{HASIL DAN DISKUSI}

\section{RESULTS (HEADING 1, UPPERCASE, TIMES NEW ROMAN 11 PT, BOLD)}

Describe the results of the study in accordance with the problems formulated / reviewed in the introduction. Results and discussion are separated. All types of the research must discuss the findings based on theory. Four important points that must be implied/explicit in the results and discussion section are: (1) (what/how) the data presented has been processed (not raw data), set out in tables or pictures (select one), and give an information that is easy to understand and pictures/ 
tables are clearly referenced; (2) (why) in the discussion section there is a connection between the results obtained and the basic concepts and/or hypotheses; (3) (what else) there is a match or contradiction with the results of other people's research; and (4) write the implications of the results of both theoretical and implementation of the research. (Times New Roman 11pt font, justify, A left-aligned paragraph, 1.5 spacing, space between paragraphs $11 \mathrm{pt})$.

\subsection{Wahyu Pertama}

Dalam penelitian ini, terdapat hal penting yang di temukan oleh peneliti yang bersumber dari data kepustakaan yang sekaligus menjawab rumusan masalah.

Quraish Shihab mengartikan bahwa wahyu adalah suatu isyarat cepat (termasuk bisikan dalam hati dan ilham) surat, tulisan dan segala hal yang disampaikan kepada orang lain untuk di ketahui (R. Baiti, 2019). Hampir senada dengan Quraish Shihab, Iu Rusliana Mengartikan wahyu sebagai firman Allah yang diturunkan kepada Nabi Muhammad SAW dalam bentuk teks atau tulisan (L. Rusliana, 2015 ).

Pada dasarnya wahyu adalah salah satu dari sumber ilmu pengetahuan, sehingga jika kita mengkaji ilmu wahyu tidak berarti kita mengabaikan ilmu pengetahuan, melainkan melalui wahyu (Al-Qur'an) Allah SWT mendorong umat manusia untuk menggali pengetahuan (R. Baiti, 2018). Pengetahuan yang di peroleh dari wahyu memiliki kedudukan yang absolute (murni) karena langsung berasal dari Allah.

Nabi Muhammad menerima atau mendapatkan wahyu pertama kali berupa surat Al-Alaq [96] 1-5 yang terdiri dari lima ayat. As babul Nuzul ayat ini adalah yakni ketika Muhammad (sebelum kenabian) mendatangi gua Hira untuk beribadah, beberapa hari kemudian datanglah malaikat Jibril menyampaikan wahyu. Malaikat tersebut berkata kepada Muhammad "bacalah" beliau menjawab "aku tidak bisa membaca" peristiwa ini terus berulang sebanyak tiga kali, barulah di ketiga kalinya Muhammad mengucapkan apa yang ucapkan malaikat (A. I. Daroini, 2018). QS. Al-Alaq [96]:1-5 Dari ayat tersebut kita mendapat mengambil kesimpulan bahwa urgensi pertama bagi seorang manusia adalah memperoleh pendidikan dimana menurut Quraish Shihab pendidikan yang terkandung di dalam ayat tersebut terbagi menjadi 3 yaitu keterampilan, ketuhanan, dan akal (A. I. Daroini, 2018). Ketiga nilai pendidikan tersebut tentunya sangat terkait dengan metafisika.

\subsection{Metafisika}

Metafisika berasal dari bahasa Yunani "meta ta phisica, yang mengandung arti "sesuatu yang terdapat sesudah fisika" atau mengkaji tentang sesuatu yang berada di balik yang fisik (Irwandra, 2014). Seyyed Hossein mengartikan metafisika sebagai ilmu pengetahuan tentang "yang real" yang menjelaskan asal-usul semua realitas yang absolut dan relatif (A. Khoirudin, 2014). Banyak orang yang beranggapan bahwa ketika membahas aspek atau kerangka pikiran filsafat yang pertama adalah ontologi, namun nyatanya itu merupakan bagian dari metafisika. Metafisika itu sendiri memiliki secara harfiah berarti "melampaui fisik" (G. R. Knight, 2007). Sedangkan 
menurut Archie J. Bahn mengatakan bahwa metafisika adalah suatu usaha untuk mengungkapkan tentang masalah keberadaan (R. Mustansyir, 2015). Lantas bagaimana metafisika sebagai pondasi pembentukan konsep pendidikan Islam?. Aktivitas pendidikan sangat tidak bisa lepas dari metafisika, bahkan melebihi dari aktivitas manusia yang lainnya (G. R. Knight, 2007). Aspek metafisika ada empat yaitu:

Pertama, Kosmologi Aspek metafisika yang mencakup tentang kajian, teori awal mula, hakikat dan perkembangan alam semesta Kosmologi berasal dari bahasa Yunani yaitu "kosmos" dan "Logos" yang berarti susunan yang baik (A. N. Rasyid, 2020) Biasanya muncul pertanyaan “apakah tujuan alam semesta?". Kedua, Teologi Aspek metafisika ini membahas tentang hakikat keberadaan Tuhan. pertanyaan yang sering muncul seperti “apakah Tuhan Itu ada?" (R. Mustansyir, 2020). Ketiga, Antropologi, Aspek yang membahas terkait hakikat manusia. Biasanya memunculkan pertanyaan seperti apa tujuan manusia di ciptakan? Keempat, Ontologi cabang filsafat yang memperbincangkan hakikat realitas. Ontologi, secara bahasa Yunani terdiri dari dua kata; on: semakna dengan being, dan logos atau Logic. Jadi ontology ialah The theory of being qua being atau teori tentang keberadaan sebagai keberadaan (M. R. Dasuki, 2019). Pembahasan ontologi hal yang sangat penting karena menyangkut persoalan dalam menemukan sebuah hakikat, yang menjadi pertanyaan mendasar dalam pembahasan ontologi yakni "apakah itu benar-benar ada?". Menurut J. Donald Butler Isology adalah padanan untuk ontologi (G. R. Knight, 2007) Sekilas pertanyaan tersebut sangatlah sederhana namun jika di maknai secara mendalam maka pertanyaan tersebut sangat perlu perenungan.

Dari penjabaran metafisika dapat di pahami bahwa fokus kajian metafisika adalah persoalan-persoalan yang berada di luar jangkauan fisik dan semuanya terkait dengan pendidikan Islam, salah satunya tentang hakikat Tuhan. sehingga anggapan bahwa pendidikan tidak dapat dilepaskan dari metafisika adalah anggapan yang benar.

\subsection{Analisis}

Pendidikan Islam erat kaitannya dengan metafisika, berikut ini analisis peneliti terkait wahyu pertama beserta contohnya yang menunjukkan keterkaitan metafisika dengan pendidikan Islam:

\section{A. Kosmologi}

Perintah membaca di dalam ayat pertama Surat Al-Alaq, mengisyaratkan kepada kita membaca segala objek yang dapat dibaca, baik yang tersurat (nash) maupun yang tersirat seperti gejala alam. Sesuai dengan artinya kosmologi membahas tentang alam semesta, maka pendidikan Islam yang berpatokan dengan Al-Qur'an, akan mengambil inspirasi tentang alam semesta misalnya seperti ayat Al-Imran (R. Mustansyir, 2015) :190 Sesungguhnya dalam penciptaan langit dan bumi, dan silih bergantinya malam dan siang terdapat tanda-tanda bagi orang-orang yang berakal, 
Sangat rasional jika membaca diturunkan sebagai wahyu pertama, Perintah membaca ini tidak menunjukkan objek secara khusus, hal ini dimaksudkan agar manusia menggali ilmu pengetahuan secara komprehensif untuk memajukan umat manusia ( C. Said, 2016). Manusia telah dibekali kompetensi sejak lahir berupa akal, maka melalui ayat ini Allah mengingatkan bahwa potensi akal yang telah di berikan harus digunakan untuk memahami ciptaan-Nya dengan begitu kita akan mengerti bahwa Allah itu benar ada dan nyata walaupun tidak terlihat secara kasat mata.

Dari ayat pertama dan ketiga terdapat kata membaca dapat diartikan bahwa dalam memperoleh ilmu pengetahuan kegiatan harus dilakukan berulang-ulang sehingga muncul suatu kebiasaan dengan kata lain bahwa ayat tersebut memberikan pemahaman bahwa dalam pendidikan perlu ditanamkan metode pembiasaan agar peserta didik lebih memahami suatu pelajaran ( S. R. Ummah, 2017).

Berbagai contoh pendidikan tentang kosmologi, misalnya seperti di dalam ajaran Islam di sampaikan bahwa penciptaan alam semesta berlangsung enam masa, ataupun ilmu falak Ilmu sebagai ilmu yang mengkaji perhitungan waktu dalam berbagai momentum ibadah sesungguhnya adalah ilmu mikat (ilm al-miqat) yaitu satu cabang disiplin astronomi mapan yang berkembang dan populer di peradaban Islam yang secara khusus mengkaji gerak benda-benda langit guna kepentingan penentuan waktu-waktu ibadah ( A. N. Rasyid, 2020).

\section{B. Teologi}

Teologi ini membahas masalah terkait ketuhanan. Dalam tradisi Islam teologi dapat diartikan sama dengan ilmu kalam, ilmu ushuluddin, ilmu tauhid, dan ilmu akidah ( S. Futaqi, 2020). Jika berkaca terhadap pendapat Quraish Shihab bahwa di dalam wahyu pertama itu terdapat pendidikan tentang ketuhanan, maka tidaklah mungkin metafisika di lepaskan dari pendidikan Islam. Kita semua tahu bahwa ajaran Islam sangatlah menjunjung aspek ketuhanan maka dari itu dengan pemahaman tentang aspek metafisika (teologi) itu sangat penting, terlebih lagi banyak sekali pemahaman-pemahaman yang bertentangan dengan ajaran Islam misalnya atheist, deist, pantheism polytheism sedangkan Islam Menganut paham monoteisme yang artinya Tuhan hanya satu yaitu Allah SWT. QS. AlAlaq [96]:1 Ayat ini mengajarkan kepada kita tentang pendidikan tauhid yang merupakan pondasi pertama dalam pendidikan Islam, sebagai mana yang di ajarkan Nabi Muhammad SAW kepada sahabat di awal-awal Islam. Serta berlaku juga pada anak-anak sebagaimana yang dilakukan Nabi Muhammad SAW yang membacakan kalimat tauhid (adzan) di telinga kedua cucunya Hasan dan Husain ( A. I. Daroini, 2018). 
Pada hakikatnya, peserta didik tidak akan mampu mengenal Tuhannya jika tidak diajarkan eksistensi dan hakikat Tuhan. Maka seorang guru harus mampu menjelaskan tentang ketuhanan dengan mengamati dan mengambil gambaran dari apa yang telah di ciptakan-Nya. Hal ini sebagai implementasi dari makna membaca. Karena di sini makna membaca itu sangat luas tidak sekedar membaca teks namun sangat luas mencakup mengumpulkan berbagai informasi melalui penelitian, kajian dan penalaran dengan kata lainnya membaca segala objek yang dapat dibaca, baik yang tersurat (nash) maupun yang tersirat ( C. Said, 2016).

Implikasi teologis dalam pendidikan Islam dapat dilihat dari dua aspek, pertama, aspek materi, penyampaian bukti tentang adanya Tuhan dapat dilakukan dengan berpedoman ayat qauliyah dan kauniyah. Ayat qauliyah sebagai sumber ilmu yang autentik bersinggungan dengan ayat-ayat tentang tanda kebesaran Allah, syariat Islam, hukum dan akhlak. Sedangkan kauniyah bersinggungan dengan segala ciptaan Allah dan berkaitan dengan perkembangan ilmu dari masa ke masa ( S. Futaqi, 2020)

Kedua, tujuan pendidikan, dalam pandangan teologi, tujuan pendidikan Islam adalah untuk mencapai ridha Allah. Hal ini sebagai penggambaran maksud Allah menciptakan manusia yaitu sebagai hamba dan khalifah di muka bumi.

Pemahaman terkait teologis menjadi salah satu sarana untuk meningkatkan kecerdasan spiritual peserta didik, yang mana kita tau kecerdasan spiritual sangat berperan penting dalam mengendalikan emosi negatif (Suyadi, 2018), pada akhirnya peserta didik akan mampu berfikir secara rasional dan memilih kegiatan yang bersifat positif untuk menghilangkan kejenuhan. Hal-hal seperti ini tentunya telah dilakukan oleh pemerintah sebagai bukti dapat dilihat dalam fatwa MUI yang mengingatkan kepada masyarakat untuk selalu menjaga kesehatan sebagai bagian dari pokok agama, umat Islam di tuntut untuk selalu mendekatkan diri kepada Allah, dengan cara memperbanyak ibadah, taubat, istigfar, zikir, qunut Nazilah di setiap solat fardu, memperbanyak solawat, sedekah, serta selau berdoa kepada Allah agar di hindarkan dari musibah (Fatwa MUI No.14 Tahun 2020).

\section{Antropologi}

Kajian antropologi berkaitan dengan hakikat manusia itu sendiri. Pengkajian tentang aspek manusia menumbuhkan pemahaman dalam pendidikan Islam bahwa manusia itu memiliki kedudukan sebagai hamba dan khalifah, sehingga potensi yang ada pada manusia harus dibina dengan baik sehingga mampu menjalankan tugasnya dan mendapat ridha Allah. QS. Al-Alaq [96]:2 Dia Telah menciptakan manusia dari segumpal darah.

Ahmad Tafsir mengatakan bahwa wahyu pertama mengandung isyarat tentang pendidikan yang mengkaji untuk memahami, menelaah, dan melakukan observasi secara 
ilmiah bagaimana tahapan penciptaan manusia mulai dari segumpal darah sampai lahir agar dapat memahami hakikat dan tujuan penciptaan manusia sebagai hamba (C. Said, 2016) Ayat kedua ini sebagai dampak dari kata membaca di ayat pertama, karena dengan membaca (mengkaji) kita akan mengetahui tentang bagaimana manusia diciptakan, ayat ini juga mengisyaratkan tentang ilmu biologi.

Penciptaan secara biologis dapat di pahami secara sains empirik, berdasar dari ayat di atas, penciptaan manusia secara biologis terjadi dalam empat tahap, dimana manusia diciptakan dari sari tanah (air mani) (nuthfah) kemudian disimpan di dalam tempat yang kokoh (rahim). Di dalam rahim air mani berubah menjadi segumpal darah ('alaqah) dan melekat di rahim seperti lintah, kemudian berubah menjadi segumpal daging (mudghah) selanjutnya di bentuklah tulang belulang lalu di bungkus dengan daging. Tahapan selanjutnya ditiupkan roh. Di dalam hadis riwayat Bukhari dan Muslim menyatakan bahwa roh ditiupkan setelah 40 hari nuthfah, 40 hari alaqah, 40 hari mudghah, yang kemudian parah ulama mengambil kesimpulan bahwa roh ditiupkan ketika janin berusia 120 hari ( M. Basyrul Muvid, 2020).

Dalam Al-Qur'an Allah SWT dalam menggunakan empat konsep dalam menyebutkan manusia yaitu Al-Basyar, Al-Insan, An-Nash dan Bani Adam ( A. S. Rizal, 2014). Pemahaman konsep manusia akan memberikan gambaran tentang tujuan dan sistem pendidikan serta mampu memahami kedudukan dan tujuan manusia di ciptakan. Berikut penjabaran manusia menurut Al-Qur'an:

Pertama, Term al-basyar dituliskan dalam Al-Qur'an berjumlah 37 kali di dalam 26 surah. Menurut al-Rahghib, kata basyar adalah jamak dari kata basyarat yang berarti kulit. Manusia disebut basyar karena kulit manusia tampak berbeda dengan kulit makhluk hidup lainnya (T. Priatna, 2018). Secara etimologi al-basyar memiliki makna mulamasah yakni persentuhan tubuh antara laki-laki dan perempun (M. Basyrul Muvid, 2020), artinya bahwa manusia memiliki segala sifat kemanusiaan, seperti makan, minum, kebahagiaan, berilmu dan lain sebagainya.

Sesuai dengan asal katanya term al-basyar juga diartikan sebagai homo biologis, dimana manusia mengalami perkembangan dan pertumbuhan, serta berkembang biak. Term al-basyar menunjukkan bahwa manusia itu sangat kompleks dan diciptakan dengan membawa fitrahnya sebagai mahluk homo biologis sehingga manusia mampu melanjutkan eksistensinya sebagai khalifah di bumi.

Kedua, Al-Insan yang diartikan secara umum adalah manusia. Kata ini di sebutkan Al-Qur'an dengan kata yang berbeda, total 73 kali tersebar di 43 surat. Secara morfologi, kata al-insan berasal dari kata nasiya-yansa berarti lupa. secara etimologi al-insan 
memiliki arti lemah lembut, dapat di lihat (tampak), dan pelupa (M. Basyrul Muvid, 2020). Manusia dikatakan lemah lembut dan tampak, hal ini karena akar kata ins yang berarti sesuatu yang terlihat (tampak) dan jinak. Sedangkan lupa disandarkan pada kata unaisiyan sebagai tashgir dari insan yang memiliki arti lupa, menurut Ibn Abbas bahwa manusia telah melupakan janjinya dengan Allah Ada pula yang mengartikan bahwa al-insan mengandung akar kata Naus yang artinya pergerakan atau dinamis (T. Priatna, 2018).

Berkaca dari pengertian tersebut dapat dipahami manusia memiliki fitrah mengalami pertumbuhan dan perkembangan secara fisik dan spiritual (homo religius). Di sisi lain sifat yang dinamis menunjukkan bahwa manusia memiliki potensi untuk menuju ke arah tindakan yang bersifat negatif dan merugikan manusia itu sendiri.

Penggunaan term Al-Insan menunjukkan manusia adalah mahluk jasmani dan rohani. Aspek tersebut harus mampu diselaraskan dengan baik sehingga potensi yang dibawah sejak diciptakan mampu mengantarkan manusia sebagai mahluk Allah yang sempurna, serta memiliki karakteristik yang berbeda antara satu dengan lainnya. perpaduan antara Al-Basyar dan Al-Insan menunjukkan bahwa manusia adalah makhluk yang berbudaya, mampu berbicara, mengetahui baik dan buruk, mengembangkan ilmu pengetahuan serta peradaban dan lain sebagainya.

Ketiga, Term An-Nas di dalam Al-Qur'an dapat ditemukan 240 kali dan tersebar di alam 53 surat. Secara umum menggambarkan sifat manusia yaitu mahluk sosial (homo psiko-sosiologis) (A. Supriadi, 2018). Contoh ayat yang menggambarkannya yaitu QS. AlHujurat [49]:13 Pada umumnya term An-Nas dikaitkan dengan fungsi manusia yaitu mahluk sosial. Penggunaan kata an-nas dapat dijumpai dan selalu dikaitkan dengan sekelompok manusia yang melakukan aktivitas atau aktivitas dalam mengembangkan kehidupannya. Sehingga dapat di maknai bahwa manusia adalah mahluk sosial yang hidup bergantung (membutuhkan) pada orang lain (M. Muhlasin, 2019).

Sesuai dengan ayat diatas manusia diciptakan sebagai mahluk bermasyarakat yang bermula dari pasangan laki-laki dan perempuan. Penggabungan antara term $\mathrm{Al}$ - basyar, AlInsan dan An-Nas menunjukkan aspek manusia sebagai mahluk sosial yang memiliki budaya, mampu mengembangkan ilmu pengetahuan dan peradaban serta berkembang biak dan lain sebagainya (D. Abdullah, 2019).

Keempat, Bani Adam Term ini dapat ditemukan tujuh kali dalam Al-Qur'an. Berasal dari kata Ban yang artinya membina, membangun, mendirikan, menyusun. Jadi bani Adam artinya keturunan anak cucu anak Nabi Adam Pendapat al-Gharib al-Ishfahany kata bani memiliki arti keturunan dari darah daging yang dilahirkan. Menurut Christyono 
Sunaryo mengungkapkan bawah Allah telah menciptakan bumi dan dunia jutaan tahun sebelum Nabi Adam diturunkan ke bumi (M. Basyrul Muvid, 2020)

Firman Allah QS. Al-Isra [17]: 70 Ayat tersebut mengungkapkan bahwa Allah memuliakan keturunan Nabi Adam (manusia) dari mahluk yang lain seperti malaikat, jin dan binatang. Dari penggabungan keempat term, bahwa manusia adalah ciptaan Allah dimulai dari Nabi Adam yang mendapat predikat sebagai mahluk sempurna yang memiliki kebudayaan, berfikir, mampu mengembangkan ilmu pengetahuan, mengembangkan peradaban secara bersama-sama sebagai mahluk sosial.

Pemahaman konsep manusia dalam Al-Qur'an akan memberikan gambaran terhadap pendidik dalam upaya pengembangan potensi yang ada pada peserta didik. Pendidikan sebagai jalan memanusiakan manusia akan membantu memahami realitas dirinya serta mampu mengaktualisasikan dirinya dalam kehidupannya sebagai makhluk yang memiliki pemahaman dan kemampuan untuk memaknai segala sesuatu dan mengetahui tujuan dan fungsi Allah SWT menciptakan manusia yaitu sebagai hamba dan khalifah.

Kedudukan Manusia di bumi adalah hamba yang harus tunduk dan beribadah kepada Allah. QS Az-Zaryat [51]: 56. Apabila di lihat dari surat Al-Alaq, Allah menegaskan bahwa Dia-lah yang menciptakan manusia. Dari asal kata (عَبََ - يَعْبُد) dengan huruf ba' berharakat fathah memiliki makna menyembah, memuja, mematuhi, berkhidmat, dan mengesakan. Apabila huruf ba' berharakat kasrah memiliki makna mencegah, mengingkari, dan membenci. Di Al-Qur'an kata 'abada disebutkan dalam berbagai bentuk. Dalam ayat tersebut di jumpai kata ya'budun sebagai kata kerja isim musytaq yang berlaku untuk orang tunggal ataupun jamak, bentuk dari isim tersebut seperti 'aabid, 'ibaad, 'abdun ( S. R. Ummah, 2019).

Sebagai hamba, manusia sepenuhnya berada di bawah naungan kekuasaan Allah, sehingga menuntut manusia untuk selalu menaati perintah dan menjauhi larangan sebagai bentuk rasa bersyukur. Bersyukurnya manusia terhadap apa yang diberikan sejatinya untuk kebaikan manusia itu sendiri, firman Allah dalam QS. Ibrahim [14]: 7. Manusia adalah mahluk yang sempurna diciptakan membawa potensi yang modal dasar dalam menjalankan fungsi dan tujuan penciptaan nya baik sebagai hamba dan khalifah. Jika dilihat dari asal kata manusia yang bersifat dinamis, maka potensi tersebut dapat digunakan untuk kemaslahatan namun juga dapat disalahgunakan. sehingga dalam mengoptimalkan potensi tersebut guna mencegah dari hal negatif, maka di perlukan pendidikan dengan harapan terwujudnya manusia yang mampu mengemban tugas Ilahi. Manusia sebagai hamba, berarti dalam kehidupan sehari-hari harus tunduk dan selalu beribadah dengan niat yang 
tulus dari hati sehingga dapat meraih Ridha Allah. Dalam beribadah perlu diingat bahwa kegiatan tersebut harus sesuai dengan tuntunan dan mengikuti petunjuk Al-Qur'an dan hadis.

Emile Durkheim mengatakan kegiatan ritual dan ibadat adalah untuk meningkatkan solidaritas, dan menghilangkan perhatian terhadap kepentingan pribadi dan lebih mengutamakan kepentingan bersama (M. Basyrul Muvid, 2020) Namun ada pula ibadah yang dilakukan sendiri misalnya doa untuk kebutuhan individu yang tidak mungkin orang lain mengetahuinya karena mengandung aib ataupun hal lainnya yang bersifat rahasia. Ibadah yang dilakukan bersama ataupun sendiri pada intinya guna mendekatkan diri kepada Allah.

Dalam pandangan Muhmidayeli manusia harus mampu merefleksikan sifat-sifat Allah ke dalam dirinya dan mengimplementasikan dalam perbuatannya. sehingga tercipta humanitas komunitas muslim sebagai potret dan lambang kebaikan dan kebijaksanaan (M. Basyrul Muvid, 2020). Sifat-sifat Allah yang dapat di terapkan seperti memiliki kehendak, ilmu, kuat, kaya, mulia, pengasih, dan penyayang.

Menurut Quraish Shihab menjabarkan konsep khalifah di dalam penelitiannya menemukan bahwa terdapat kata dua kali khalifah dalam bentuk tunggal (QS. AlBaqarah:30 dan Shad:26) dan dalam bentuk (prural) jamak, yaitu khala'if yang terulang empat kali dan khulafa' terulang tiga kali (L. Hakim, 2018) Untuk menjalakan fungsi dan tugasnya sebagai khalifah Allah menurunkan Al-Qur'an sebagai pedoman dan di sokong oleh fitrah tauhid.

Penciptaan Manusia sebagai khalifah di bumi merupakan anugerah yang patut kita syukuri dengan cara menaati segala perintah-Nya dan menjauhi larangan-Nya. Allah menyediakan alam semesta dan memberikan ilmu pengetahuan sehingga manusia dapat untuk memanfaatkannya sebaik mungkin dengan catatan tidak melakukan kerusakan.

Walaupun manusia di angkat sebagai khalifah, namun hubungan manusia dengan alam atau hubungan manusia dengan sesamanya, bukanlah hubungan tentang penaklukan dengan yang di taklukan, melainkan hubungan kebersamaan dalam ketundukan dan ketaatan kepada Allah. pendapat ini dikutip oleh Basyrul Muvid, dkk dari buku Quraish Shihab "membumikan Al-Qur'an", walaupun manusia mampu mengelola (menguasai), namun bukan karena kekuatan dari manusia melainkan karena di sebabkan Allah menundukkan semuanya untuk manusia. QS. Al-Jatsiyah (45):13 Menurut Musa Asy'are tugas sebagai manusia sebagai khalifah mengandung pesan moral, kepemimpinan yang di pegang oleh manusia dapat digunakan untuk kepentingan dan kemaslahatan bersama atau sebaliknya disalahgunakan untuk kepentingan pribadi dan mengejar hawa nafsu 
negatifnya. Dengan tercapainya hal tersebut maka manusia mampu mencapai derajat hamba Allah yang baik dan taat.

Antropologi dalam pendidikan Islam Pendidikan Islam sangatlah penting, sebagai contoh dalam pendidikan Agama Islam diajarkan sedekah, salah satu hikmah yang dapat di petik dari sedekah dalam bentuk makanan, uang dan kebutuhan pokok lainnya yaitu merasakan empati atau kepedulian terhadap orang lain, konsep penting di terapkan terlebih saat ini masa pandemi COVID-19 banyak orang-orang yang mengalami kendala ekonomi. Contoh lain pendidikan Islam mengajarkan untuk menjaga kebersihan, tentunya ini sebagai buah dari pemahaman bahwa manusia itu harus selalu menjaga kebersihan dan lingkungannya agar terhindar dari berbagai penyakit terlebih di masa pandemi.

Aspek Ontologi ini fokus kajian tentang hakikat. Dalam dunia pendidikan, tidak dapat dilepaskan dari aspek ontologi sebagai kajian realitas, hal ini karena sangatlah penting bahwa proses pendidikan didasarkan atas fakta dan realitas bukan berdasarkan ilusi, khayalan, angan-angan dan asumsi.

Sebagai contoh apakah yang nyata dari lantai yang kita injak? Melaui indera mata kita akan menjawab bahwa lanai itu datar, padat, halus, terbuat dari bahan tertentu misal keramik. Namun jika ahli kimia yang menjawab pertanyaan tersebut maka lantai itu terbuat dari struktur himpunan hidrokarbon yang menyatu dengan cara tertentu dan dipengaruhi oleh lingkungan.

Dari penjelasan diatas kita melihat bahwa persoalan realitas lantai saja menimbulkan banyak jawaban dan membingungkan, sehingga realitas bukan hal yang sesederhana apa yang terlihat sekilas. Tanpa ontologi tidak akan mungkin ada suatu kalian yang mendalam dari persoalan yang dibahas, namun sebaliknya jika dikaji dengan ontologi akan muncul berbagai jawaban dan hal-hal yang berhubungan dengan hal yang sedang dikaji (M. R. Dasuki, 2019)

Melalui wahyu pertama (Al-Alaq 1-5), ayat tersebut menunjukkan tentang contoh hakikat, mulai dari hakikat Tuhan serta hakikat manusia. Dalam dunia pendidikan, tidak dapat dilepaskan dari aspek ontologi sebagai kajian realitas, hal ini karena sangatlah penting bahwa proses pendidikan didasarkan atas fakta dan realitas bukan berdasarkan ilusi, khayalan.

Sejalan dengan hal tersebut, ajaran agama Islam menuntut untuk selalu jujur dalam setiap aspek kehidupan, hal ini sudah di contoh kan Nabi Muhammad SAW yang senantiasa jujur dalam kehidupannya. Oleh karena itu pendidikan Islam juga wajib bersifat jujur dalam artian mengajarkan hal yang bersifat fakta, ketika menjelaskan ajaran agama dan ketuhanan serta diimplementasikan dalam kehidupan sehari-hari dan mengambil 
contoh dari apa yang telah diciptakan oleh Allah SWT untuk membuktikan bahwa Allah itu ada dan Esa (satu). Dengan demikian ontologi tidak dapat dipisahkan dari Allah selaku pencipta manusia (M. Basyrul Muvid, 2020)

Dalam pemahaman ontologi pendidikan Islam dapat di contoh kan dalam pembelajaran tentang iman yakni mengajarkan peserta didik untuk percaya bahwa Allah SWT itu ada. Hamzah Lubis menyampaikan bahwa pendidikan keimanan mutlak diperlukan agar potensi iman dalam diri anak dapat berkembang sesuai dengan tuntutan ajaran keimanan dalam Islam (D. Ilham, 2020).

Keindahan dan bernilai nya pendidikan Islam yaitu ketika tujuan pendidikan tercapai yaitu terwujudnya pola kehidupan manusia yang bertakwa kepada Allah SWT, dalam rangka kesejahteraan dunia dan akhirat, melalui pembinaan, latihan kejiwaan, penalaran otak, perasaan dan panca indera. Singkatnya pendidikan Islam mencakup aspek jasmani, spiritual, dan intelektual (K. Kambali, 2019). Dari penjabaran diatas terungkap bahwa metafisika sangat penting bagi pendidikan Islam, hal ini tertuang di dalam wahyu pertama yang di dalamnya memuat tentang hakikat Tuhan, ciptaan-Nya dan Manusia. Melalui metafisika sebagai ilmu yang membahas hakikat sangat membantu dalam memahami dan menyampaikan hal-hal yang di luar akal misalnya hakikat Tuhan, sehingga dapat dipahami bahwa metafisika sangat berperan penting dalam penanaman sikap spiritual siswa.

\section{Kesimpulan}

Al-Alaq ayat 1-5 adalah wahyu pertama yang diturunkan Allah kepada Nabi Muhammad. Dalam ayat tersebut Quraish Shihab menyebutkan bahwa ada tiga nilai pendidikan yang dapat di ambil yaitu pendidikan keterampilan, ketuhanan dan pendidikan akal. Melalui kajian metafisika (kosmologi, teologis, antropologi dan ontologi) dapat di gali hakikat keberadaan Tuhan dan Manusia serta metafisika sangat berperan penting dalam penanaman sikap spiritual siswa. Karena hal itu pula maka pendidikan Islam tidak dapat di pisahkan dari persoalan yang bersifat metafisika atau di luar jangkauan fisik.

\section{REFERENSI}

L. Rusliana, Filsafat Ilmu. Bandung: PT Refika Aditama, 2015.

G. R. Knight, Filsafat Pendidikan. Yogyakarta: Gama media, 2007.

R. Mustansyir dan M. Munir, Filsafat Ilmu, 14 ed. Yogyakarta: Pustaka Pelajar, 2015.

A. Purwanto dkk., "Studi Eksploratif Dampak Pandemi COVID-19 Terhadap Proses Pembelajaran Online di Sekolah Dasar," 
S. Suyadi, Teori Pembelajaran Anak Usia Dini Dalam Kajian Neurosains. Bandung: PT Remaja Rosdakarya, 2017.

M. R. Dasuki, "Tiga Aspek Utama Dalam Kajian Filsafat Ilmu Ontologi Epistemologi, dan Aksiologi," Proceding Univ. Pamulang, hlm. 81-85, 2019.

[A. W. Fajriana dan M. A. Aliyah, "Tantangan Guru dalam Meningkatan Mutu Pendidikan Agama Islam Di Era Melenial,” Nazhruna J. Pendidik. Islam, vol. 2, no. 2, hlm. 246-265, Agu 2019, doi: 10.31538/nzh.v2i2.324.

Emzir, Metodologi Penelitian Kualitatif Analisis Data. Jakarta: PT Raja Grafindo Persada, 2014.

R. Baiti dan A. Razzaq, "Esensi Wahyu Dan Ilmu Pengetahuan," vol. 18, no. 2, hlm. 163-178, Feb 2018, doi: https://doi.org/https://doi.org/10.19109/wardah.v18i2.1776.

A. I. Daroini, "Tafsir Ayat Pendidikan Dalam Q.S Al-'Alaq Ayat 1-5 Menurut Quraish Shihab," hlm. 96, 2018.

Irwandra, "Metafisika Akhlak: Dasar-dasar Akhlak dalam Islam," -Nida Jurnal Pemikiran. Islam, vol. 39, no. 1, hlm. 92-106, 2014.

A. Khoirudin, "Rekonstruksi Metafisika Seyyed Hossein Nasr dan Pendidikan Spiritual," Afkaruna, vol. 10, no. 2, hlm. 202-216, 2014, doi: 10.18196/aiijis.2014.0038.202-216.

M. Kristiawan, Filsafat Pendidikan The Choice Is Yours. Yogyakarta: Valia Pustaka, 2016.

A. N. Rasyid, “Astronomi Dan Kosmologi Dalam Perspektif Al Qur'an,” Vektor J. Pendidik. IPA, vol. 1, no. 1, hlm. 39-49, 2020.

C. Said, "Paradigma Pendidikan Dalam Perspektif Surah Al-Alaq Ayat 1-5," Hunafa J. Studi Islam., vol. 13, no. 1, hlm. 91-117, Jul 2016, doi: 10.24239/jsi.v13i1.415.91-117.

S. R. Ummah, "Relevansi Perintah Iqra' Pada Wahyu Pertama Bagi Masyrakat Modern," Pancawahana J. Studi Islam, vol. 12, no. 1, hlm. 21-38, 2017.

S. Futaqi, "Memperkokoh Basis Teologis Pendidikan Islam," Ta"lim J. Studi Pendidik. Islam, vol. 3, no. 1, hlm. 114-127, Jan 2020.

"Fatwah MUI No.14 Tahun 2020.” Apr 04, 2020, [Daring]. Tersedia pada: https://covid19.go.id/p/ protokol/fatwa-majelis-ulama-indonesia-nomor-14-tahun-2020-tentang-penyelenggaran-ibadahdalam-situasi-terjadi-wabah-covid-19.

M. Basyrul Muvid, L. Zumroti, M. Abdullah, dan Moch. Faizin Muflich, Filsafat Pendidikan Islam. Yogyakarta: Pustaka Pelajar, 2020.

A. S. Rizal, "Filsafat Pendidikan Islam Sebagai Landasan Membangun Sistem Pendidikan Islam," vol. 12, no. 1, hlm. 1-18, 2014.

T. Priatna dan T. Ratnasih, “Konsep Manusia Dalam Al-Qur'an,” Digit. Libr. UIN Sunan Gunung Jati, hlm. 18, Mei 2018.

A. Supriadi, Kecerdasan Seksual Dalam Al-Quran. Yogyakarta: Idea Press, 2018. 
M. Muhlasin, “Konsep Manusia Dalam Perspektif Al-Qur'an,” Idarotuna, vol. 1, no. 2, hlm. 4660, Mei 2019, doi: 10.24014/idarotuna.v1i2.7025.

Universitas Islam Negeri Alauddin Makassar dan D. Abdullah, "Konsep Manusia Dalam Al-Qur'an (Telaah Kritis tentang Makna dan Eksistensi)," Al Daulah J. Huk. Pidana Dan Ketatanegaraan, vol. 6, no. 2, hlm. 331-344, Des 2017, doi: 10.24252/ad.v6i2.4886.

S. R. Ummah, "Konsep Manusia Sebagai Hambah Dalam Al Qur'an Dan Peranannya Dalam Kehidupan Bermasyarakat (Kajian Tafsir Tematik Dengan Pendekatan Bahasa)," Pancawahan J. Studi Islam, vol. 14, no. 2, hlm. 70-86, 2019.

L. Hakim, "Konsep Khalifah fil Ardhi dalam Perspektif Filsafat: Kajian Eksistensi Manusai sebagai Khalifah," Intizar, vol. 24, no. 1, hlm. 37-54, 2018, doi: 10.19109/ intizar.v24i1.1968.

D. Ilham, "Persoalan-Persoalan Pendidikan dalam Kajian Filsafat Pendidikan Islam," Didaktika, vol. 9, no. 2, hlm. 10, 2020.

K. Kambali, I. Ayunina, dan A. Mujani, "Tujuan Pendidikan Islam Dalam Membangun Karakter Siswa Di Era Digital (Studi Analisis Pemikiran Pendidikan Islam Abuddin Nata)," Risâlah J. Pendidik. Dan Studi Islam, vol. 6, no. 1, hlm. 1-19, Sep 2019, doi: 10.31943/ jurnal_risalah.v6i1.106. 